\title{
Pollen morphology of four species of Jatropha (Euphorbiaceae), including toxic varieties, in Northwestern Mexico
}

\author{
Federico Soto-Landeros ${ }^{1}$, Lilia Alcaraz-Meléndez ${ }^{1 *}$, Miguel A. Angulo-Escalante ${ }^{2}$, \\ Teodoro Reynoso-Granados ${ }^{1}$, Pedro Cruz-Hernández ${ }^{1} \&$ Filiberto Herrera-Cedano $^{3}$ \\ 1. Centro de Investigaciones Biológicas del Noroeste, S.C. La Paz, Baja California Sur, México; \\ fsoto@cibnor.mx, lalcaraz04@cibnor.mx, treynoso04@cibnor.mx,pcruz@cibnor.mx \\ 2. Centro de Investigación en Alimentación y Desarrollo, A.C. Coordinación, Culiacán, Sinaloa, México; \\ mangulo@ciad.edu.mx \\ 3. Instituto Nacional de Investigaciones Forestales, Agrícolas y Pecuarias, INIFAP, Nayarit, México; \\ herrera.filiberto@inifap.gob.mx \\ * Correspondence
}

Received 26-V-2016. Corrected 11-I-2017. Accepted 27-I-2017.

\begin{abstract}
Jatropha curcas is a native Mexican plant, distributed in the forests of coastal regions; it has shown potential for the production of biofuel, and its raw protein can be used as animal feed. Nevertheless, its current varieties have low yield and production variability, as it is in domestication period. The knowledge of the pollen grains is fundamental for studies of Jatropha reproductive biology and breeding for genetic improvement to generate new hybrids and improve fruit and seed yield. This study compared pollen morphology of four Jatropha species, which include two varieties of $J$. curcas (one toxic from India and one non-toxic from Mexico), and two varieties of wild $J$. cinerea (Sinaloa and Baja California Sur); additionally, pollen was collected from wild J. platyphylla (Sinaloa) and J. vernicosa (Baja California Sur) to characterize them palynologically. We used a scanning electron microscope to describe the size and shape of pollen grains. Pollen grains were observed spheroidal. The diameter of the varieties of toxic and non-toxic $J$. curcas and that of J. platyphylla were $58 \pm 2.3,54$ \pm 1.7 , and $51 \pm 2.4 \mu \mathrm{m}$, respectively; the number of clavae was $84 \pm 10,108 \pm 15$, and $180 \pm 15.5$, respectively. Pollen grains of $J$. cinerea (Sinaloa) had a diameter of $50 \pm 1.7 \mu \mathrm{m}$ and $220 \pm 14$ clavae by area; J. cinerea (Baja California Sur) had a diameter of $45 \pm 1.9 \mu \mathrm{m}$ and $195 \pm 14.7$ clavae. Pollen grains of $J$. vernicosa had a diameter of $46 \pm 2.1 \mu \mathrm{m}$ and $231 \pm 25.6$ clavae. The ornamentation of the exine showed clava with capita gemma shaped for varieties of $J$. curcas species and clavum shaped for J. platyphylla, J. cinerea and $J$. vernicosa species. The studied varieties have a cross-linked endexine and ectexine intectate. Luminal bacules were observed in the reticular space of $J$. curcas varieties while none were present in the varieties of J. cinerea, J. platyphylla, and J. vernicosa. Rev. Biol. Trop. 65 (2): 799-806. Epub 2017 June 01.
\end{abstract}

Key words: Palynology, J. curcas (toxic and non-toxic var.), J. cinerea, J. platyphylla, J. vernicosa, endemic plant.

The name Jatropha (Euphorbiaceae) is derived from the Greek words "iatros" meaning physician or doctor and "trophe" nutrition or food (Heller, 1996), which is indicative of its potency and widespread use as a medicinal herb during ancient times (Sunil, Kuma, \& Varaprasad, 2013). Recently $J$. curcas is considered a source for biodiesel (Bahadur, Murthy, \& Sujatha, 2013) and flour production, with a great potential for animal feed (Escoto-González, Flores-Ceballos, \& MaytorenaGarcía, 2013). The genus Jatropha contains approximately 170 to 175 known species (Dehgan \& Webster, 1979; Heller, 1996), including $J$. curcas, J. cinerea, J. platyphylla, and $J$. vernicosa.

Jatropha curcas (L) is considered as the most primitive species in the genus (Wilbur, 
1954; McVaugh, 1945). The origin of this species has long been debated, but it has been agreed that it is native to Mexico and Continental America (Achten et al., 2010). A non-toxic $J$. curcas variety has been found only in Mexico (Jongschaap, Corré, Bindraban, \& Brandenburg, 2007) in the forests of coastal regions. The plants are monoecious with masculine and feminine flowers in the same inflorescence (Chang-wei, Kun, You, \& Yongyu, 2007). Normally, inflorescences produce a central female flower surrounded by a group of male flowers, which normally include 1-5 female flowers and 25-93 male flowers (Raju \& Bahadur, 2013). Masculine flowers have ten stamens arranged in two tiers of five each. The lower tier is free while the upper tier is united at the base, with yellow anthers. The anthers dehisce by longitudinal slits one $\mathrm{hr}$ after flower opening. The pollen grains are yellow, from spheroidal to globular, and measure from 81 to $89 \mu \mathrm{m}$ (Rianti, Suryobroto, \& Atmowidi, 2010).

Erdtman (1952) was the first one to study Jatropha pollen, proposing the descriptive term "crotonoid" to characterize the type of sculptural pattern of the exine found in some members of the family Euphorbiaceae, especially in the subfamily Crotonoideae. Bahadur et al., (2000, 2013) not only described the general aspect of pollen grains of Jatropha species found in India, but also from outside India, including $J$. curcas. Our study discusses a comprehensive analysis update of light microscopy (LM) and scanning electron microscopy (SEM) studies of the pollen of all Jatropha species to date, including $J$. cinerea .

Jatropha cinerea [(C.G. Ortega) Muell.Arg] is a drought resistant shrub 1-3 m high distributed from Arizona to the coasts of Sinaloa in Mexico. The species has mainly monoecious plants but also genotypes with dioecious plants are found, a non-typical behavior in some disturbed areas. Heart-shaped leaves are $5 \mathrm{~cm}$ diameter with palmate venation; staminate flowers show 2 or 3 individual flowers in the apical bud (Dehgan \& Webster, 1979), and the pollen grains are spheroidal of
$58 \mu \mathrm{m}$ in diameter inaperturate (Bahadur et al., 2013). The seeds are small, brown shell, and pearl white kernel. Sosa-Segura et al., (2014) mentioned that $J$. cinerea oils have a fatty acid profile similar to those of $J$. curcas and J. platyphylla.

Jatropha platyphylla (Muell.-Arg) is a drought-resistant dioecious perennial tree 2-5 m high found from Sinaloa to Michoacán, México (Sosa-Segura et al., 2014); native $J$. platyphylla from Sinaloa contains $60 \%$ kernel oil, rich in oleic $(23 \%)$ and linoleic acids (54\%) (Makkar et al., 2011).

Jatropha vernicosa (Brandegee) is a monoecious shrub 2-3 m tall with simple leaves and bright pedicellate. Flowering occurs in August and September; after the summer rains, it develops white flower inflorescence. The fruit is a capsule with three seeds. It is found in Baja California Sur, only in mountain areas of the Sierra de la Laguna and the Sierra de la Giganta. Latex and bark are used to relieve tooth pain and heal wounds (León de la Luz, Domínguez-Cadena, Domínguez-León, \& Coria-Benet, 2014).

Jatropha species have cross-pollination that allows a high degree of genetic variation, offering a wide array of possibilities to select the desired characteristics in cultivations (Salinas, Armijos, Jiménez, \& Proaño, 2011). Saenz de Rivas (1976) mentioned that pollen sculpture is an important taxonomic characteristic because it is easy to observe, and it is constant within the same taxon. However, some of these Jatropha species have not been described palynologically, thus accurate species diagnosis and classification are necessary.

This work describes the pollen morphology of one toxic $J$. curcas species from India, its non-toxic variety from Mexican Sinaloa state, and three natives species of México $(J$. cinerea, J. platyphylla and J. vernicosa) using the scanning electron microscopy technique, to compare surface shape and exine texture of pollen grains, whose palynodata has not been provided up to date by other researchers of Jatropha plants in Mexico. 


\section{MATERIALS AND METHODS}

Study site: Pollen from the toxic variety of $J$. curcas from India (IND) BIOD1 was collected from an experimental cultivation field of Foundation Produce Sinaloa, (25'49'25.7' $\mathrm{N}$ - 108 16'08.0" W, 85 masl). Pollen from the non-toxic $J$. curcas variety from Sinaloa (SIN), México was collected from an experimental cultivation field $\left(23^{\circ} 46^{\prime} 35.4^{\prime \prime} \mathrm{N}\right.$ $106^{\circ} 46^{\prime} 48.3$ " W, 42 masl). Pollen collected from the native species $J$. cinerea (244' $43.9^{\prime \prime}$ $\mathrm{N}-108^{\circ} 01^{\prime} 26.6^{\prime \prime} \mathrm{W}, 5$ masl), and $J$. platyphylla $\left(23^{\circ} 31^{\prime} 52.7^{\prime \prime} \mathrm{N}-106^{\circ} 30^{\prime} 12.1\right.$ ” W, 48 masl), were from wild plants variety Sinaloa (SIN). Finally, pollen was collected from wild J. cinerea $\left(23^{\circ} 45^{\prime} 06.2^{\prime \prime} \mathrm{N}-110^{\circ} 07^{\prime} 03.5^{\prime \prime} \mathrm{W}\right.$, 452 masl) and $J$. vernicosa $\left(23^{\circ} 42^{\prime} 04.1^{\prime \prime} \mathrm{N}\right.$ $\left.110^{\circ} 00^{\prime} 56.2^{\prime \prime} \mathrm{W}, 601 \mathrm{masl}\right)$, plant variety Baja California Sur (BCS), México.

For the study, four plants of each variety were selected, and five flowers from each one of them were obtained for pollen samples in September 2015; the flower samples were mixed and placed in Eppendorf tubes with
$2 \mathrm{ml}$ of $10 \%$ glutaraldehyde in duplicate. In December 2015, the samples were dehydrated gradually with ethanol at $20,40,60,80$, and $100 \%$ for $30 \mathrm{~min}$ each one of them (Erdtman, 1952) and placed in a critical drying chamber (Samdri-PVT-3D®, MD, USA), where alcohol was substituted by $\mathrm{CO}_{2}$ to maintain pollen shape. The samples were placed in aluminum sheets coated with gold (Denton Vacuum Desk $11 \AA, S C$, USA). Observation was performed in the Scanning Electron Microscope at a distance of $15 \mathrm{~mm}$ and a voltage of $15.0 \mathrm{kV}$ (Hitachi S-30000N).

Pollen grains characterization was performed according to a glossary of palynological terms (Sáenz-Laín, 2004). The number of bacula was counted from 60 pollen grains in a scale of $900 \mu \mathrm{m}^{2}$ where the counting area was the center of the pollen grains and subdivided in $10 \mu \mathrm{m}^{2}$ squares. Pollen counting was performed by processing the micrographs in the program Paint and dividing it in nine squares (Fig. 1). The statistical test ANOVA was performed to compare the length of the equatorial

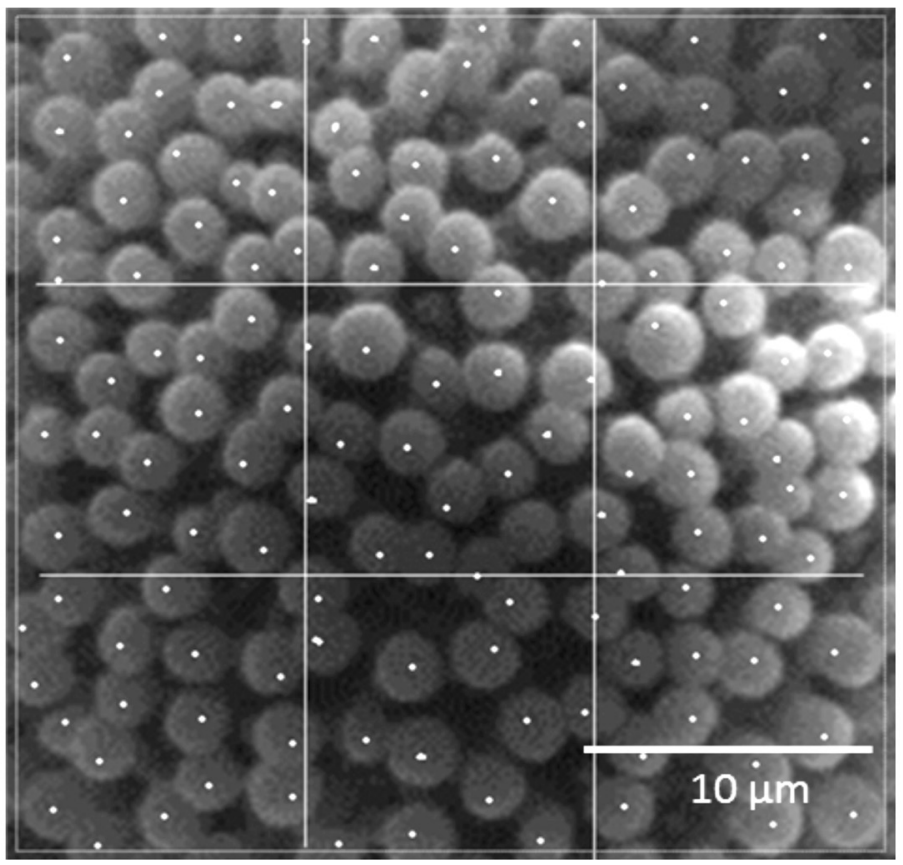

Fig. 1. Pollen micrograph of Jatropha curcas count number of clavae per $900 \mu \mathrm{m}^{2}$. 
axis of 60 pollen grains and the number of bacula of the species studied.

\section{RESULTS}

All studied varieties $($ India $=$ IND, Sinaloa $=\mathrm{SIN}$ and Baja California Sur $=\mathrm{BCS}$ ) pollen grains are inaperturate and show crotonoid sculpture; a croton sculpture refers to the presence of polygonal elements (Fig. 1). The variance analysis for clavae count by variety showed a significant difference $(\mathrm{P} \geq 0.05)$ between the species of Jatropha genus; however; between the species of $J$. cinerea and $J$. vernicosa no significant differences were observed (Table 1).

The micrographs obtained from the varieties of India (IND) (toxic J. curcas) Sinaloa (SIN) (non-toxic J. curcas and J. platyphylla) showed that pollen grains had a spheroidal shape and measured in average $58 \pm 2.3,54 \pm$ 1.7 and $51 \pm 2.4 \mu \mathrm{m}$ in diameter, respectively (Table 1). The pollen grain sculpture, ornamentation or relief was formed by sculptural elements called clava in gemma shape. Clava measured $2 \mu \mathrm{m}$ in height and $2 \mu \mathrm{m}$ in their widest or capita part with 10 to 12 vertical striations slightly visible (Fig. 2), except for the variety $J$. platyphylla, which showed notably that clavae were distributed in pentagon or hexagon manner forming a net. Within this geometrical structure, elements smaller than 1 $\mu \mathrm{m}$ called luminal bacules were found only in toxic and non-toxic $J$. curcas.

The pollen grains of toxic $J$. curcas shared a similar shape to those of non-toxic germ plasma and measured $58 \pm 2.3 \mu \mathrm{m}$ in average without visible apertures. Endexine was in reticulated shape, and ectexine was intectate. Clavae were in gemma shape with $2 \mu \mathrm{m}$ in height and $2 \mu \mathrm{m}$ in capita. They showed from 10 to 12 well differentiated striations, different from the clavae of non-toxic Sinaloa variety (Fig. 3).

Clavae distribution was in similar shape to those in non-toxic varieties (pentagonal or hexagonal). The bacules among the clavae were in a size less than $1 \mu \mathrm{m}$, and they were found

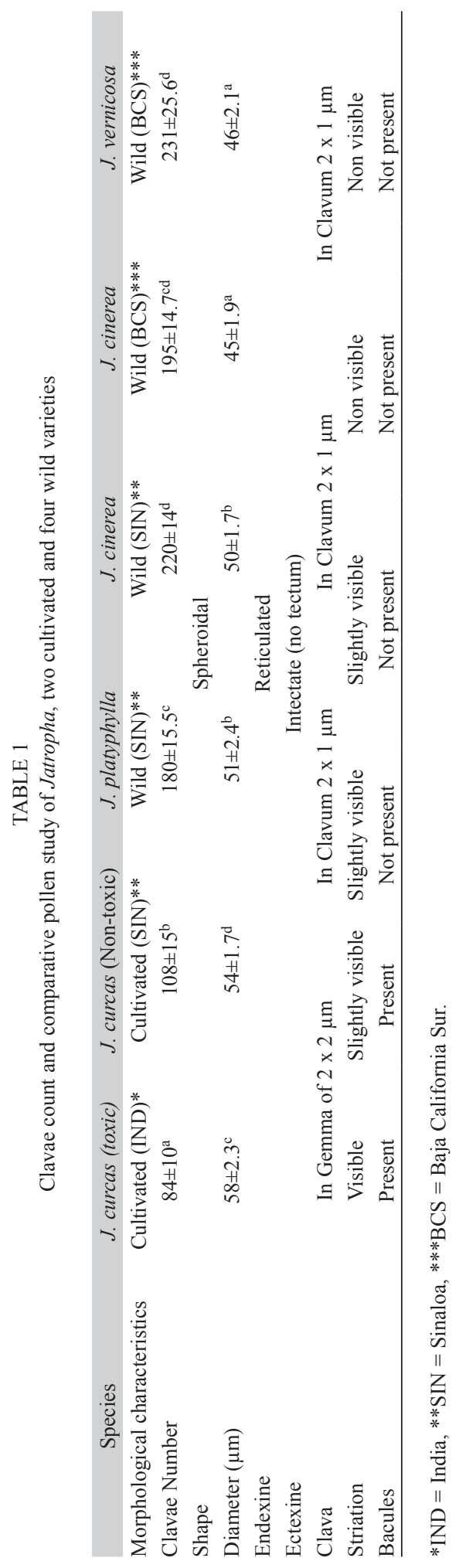



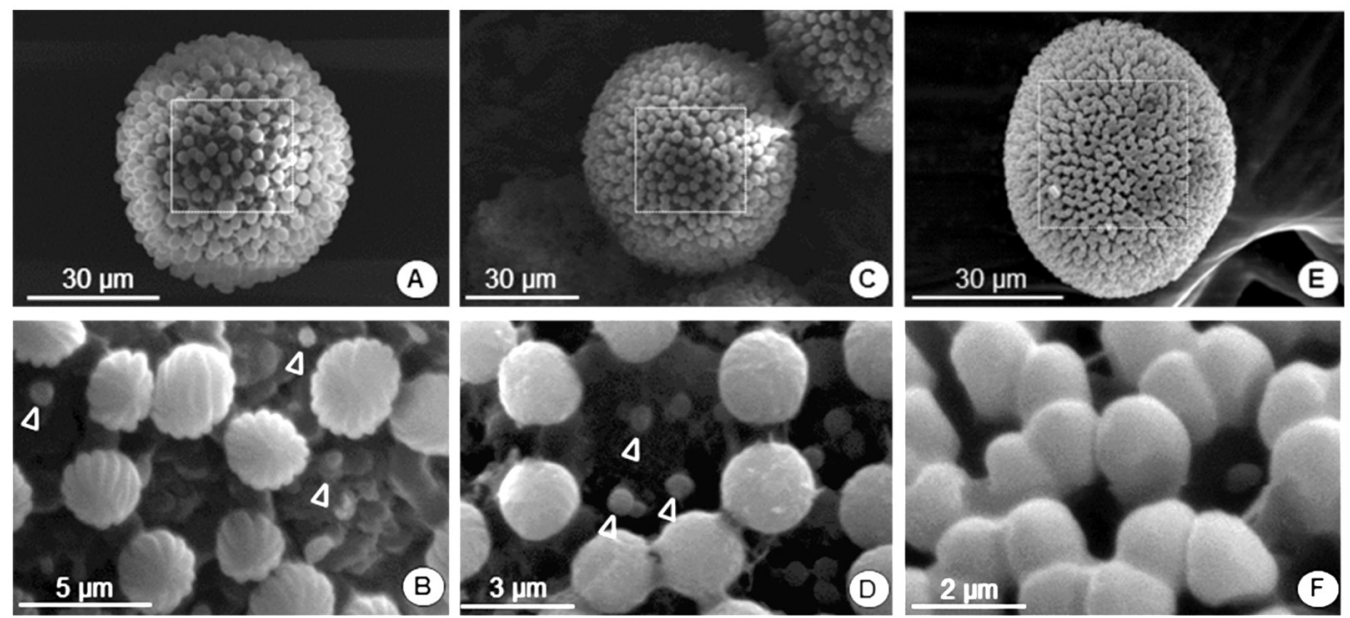

Fig. 2. Pollen micrographies of toxic Jatropha curcas variety India: A, B; of non-toxic Jatropha curcas: C, D; and Jatropha platyphylla: E, F, varieties of Sinaloa, México; verrucae: $\Delta$.
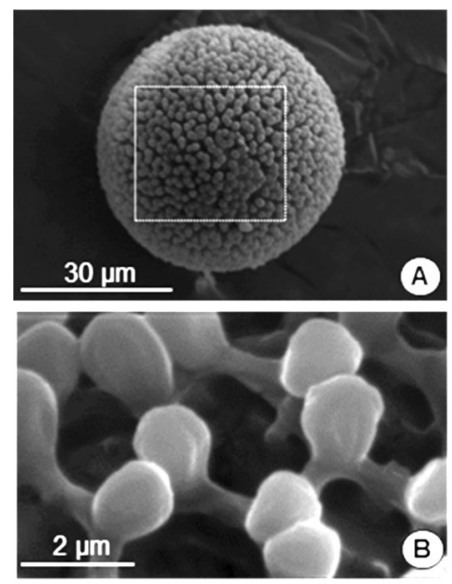
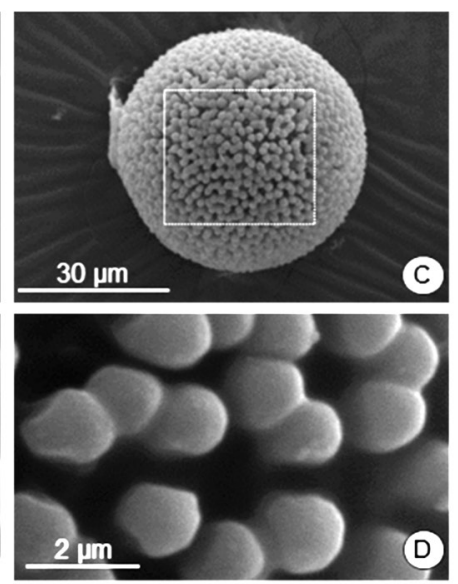
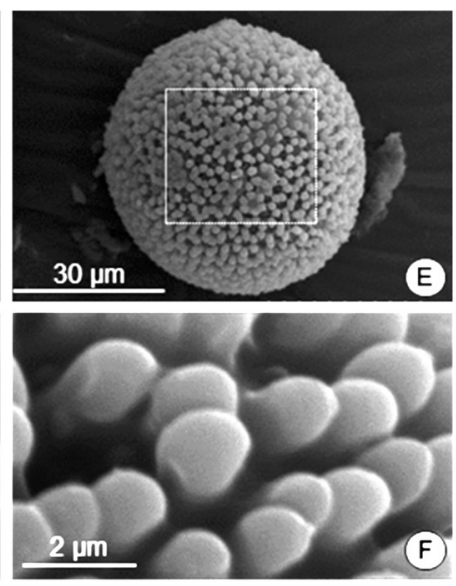

Fig. 3. Pollen micrographies of Jatropha cinerea variety Sinaloa: A, B; Jatropha cinerea: C, D; and Jatropha vernicosa: E, F, varieties of Baja California Sur.

in fewer amounts when compared with the nontoxic varieties of $J$. curcas.

Pollen of $J$. cinerea measured $50 \mu \mathrm{m}$ in diameter. Its pollen grains were smaller than those of $J$. curcas toxic and non-toxic varieties. They showed a higher number of clavae in the surface, $220 \pm 14$ in average per $900 \mu \mathrm{m}^{2}$ (Table 1), and no apertures were observed. Endexine was reticulated, and ectexine was intectate. Clava measured $2 \mu \mathrm{m}$ in height and $1 \mu \mathrm{m}$ capita in width, showing a clavum shape with six striations slightly visible (Fig. 3). Clavae were distributed in groups of five, six, and seven, inserted on the reticula and not showing bacules among them.

A comparative study was performed to concentrate information on pollen differences and similarities of the toxic and non-toxic $J$. curcas varieties and those of the wild $J$. cinerea, J. platyphylla, and $J$. vernicosa species (Table 1). Pollen grains of the four species showed a great similarity in shape without 
apertures, characters, and ornamentation. The pollen grains differed only in minor points between species. J. cinerea, J. platyphylla, and $J$. vernicosa showed a great similarity in shape and size, and the exine characters were very much alike. The most distinctive differences were found in toxic and non-toxic $J$. curcas. Differences were found among Jatropha varieties as to pollen shape and clava dimensions.

\section{DISCUSSION}

Bahadur et al., $(2000,2013)$ reported that $J$. curcas pollen was spheroidal with 61.6 $\mu \mathrm{m}$ in diameter, inaperturate, highly sculptured with clavae aligned reticulately (hexa or polygonal) with a crotonoid process. The clava or stack heads were more or less rounded with vertical striation. J. cinerea pollen was spheroidal with $58.0 \mu \mathrm{m}$ in diameter without apertures, highly sculptured with reticular clavae or stack alignment (penta or hexagonal) with crotonoid pattern. The clavae heads were triangular or polygonal vertical striation; no images were provided though.

No germination apertures were observed. According to Saenz de Rivas (1976), exine is composed by endexine, which is an internal reticulated layer, and by an external gemmate layer called ectexine that shows a striate without tectum. Bahadur et al., (2013) mentioned that $J$. curcas varieties from India were related with $J$. curcas from Africa and some endemic varieties from Mexico.

Dehgan (1984) mentioned hybrid development among $J$. curcas genotypes as parental female and $J$. cinerea as parental masculine. This fertilization could be due to the fact that the pollen grain is smaller than that of $J$. curcas and could be easily trapped by the style of the feminine flower and germinate. Successful hybridization between members of different sub-sections indicates that the various taxa in Jatropha are phylogenetically related (Sujatha, Bahadur, \& Reddy, 2013).

Pollination experiments indicated that $J$. curcas was capable of both self and cross-pollination. Observation has shown that a single female stigma of a $J$. curcas was usually provided with two-four lobes, and the stigma surface was provided with many convexes and concaves, which helped to adhere and embed pollen. In general, a plant will choose pollen from another plant to complete fertilization (Wang \& Ding, 2012). The pollenstigma interactions in Jatropha crosses are a clear indication of an active pollen-stigma recognition-rejection phenomenon. In crosses with $J$. curcas as female, pollen grains of $J$. podagrica, J. hastata and J. multifida failed to germinate. These crosses showed strong crossincompatibility and pollen germination was confined to the stigmatic surface which was arrested with coiled or spathulate pollen tips. Other motives were interspecific gene transfer is generally limited by crossability barriers, ploidy differences, and genetic distance of taxa (Sujatha et al., 2013).

$J$. curcas and its allied taxa grow in tropical mesic forest regions whereas the taxa with reduced vascular bundles are most advanced and occur in dry, warm deserts (Dehgan \& Webster, 1979). Interestingly, the monoecious $J$. curcas crosses readily with the dioecious species $J$. cinerea (Sujatha et al., 2013), J. platyphylla, and $J$. vernicosa. Most of the Jatropha species, with the exception of J. curcas, produce flowering flushes continuously throughout the year, whose attribute can be transferred to J. curcas to enhance its seed/oil yield potential (Sujatha et al., 2013). Also, J. platyphylla with its larger seed size (two-three folds higher than J. curcas) and high oil content (60\% on kernel basis) could be exploited in an interspecific hybridization program for improved seed traits (Makkar et al., 2011).

This work reports the first palynological descriptions of four species of Jatropha in Northwestern Mexico, non-toxic J. curcas, J. cinerea, J. platyphylla, and J. vernicosa. The similarities found in the morphological features in the species pollen phylogenetically matched those assigned to the genus. According to the palynological morphological characteristics, exine shape, size, and ornamentation are elements that make the taxonomic identification 
of the genus Jatropha easier among species. Knowledge about the degree of genetic diversity among and within natural populations is a prerequisite to find the genetic material necessary to breed high yielding cultivars.

\section{ACKNOWLEDGMENTS}

Our gratitude to Consejo Nacional de Ciencia y Tecnología (CONACyT) for scholarship No. 353132, to Foundation Produce Sinaloa for providing the material of toxic Jatropha curcas from India; to CIBNOR staff Ariel Cruz Villacorta for his support in electron microscopy techniques; Sergio Real Cosío and Margarito Rodríguez Álvarez for technical support, and to Diana Dorantes Salas for English edition.

\section{RESUMEN}

Morfología del polen de cuatro especies de Jatropha (Euphorbiaceae), incluyendo variedades tóxicas, en el noroeste de México. Jatropha curcas es nativa de México, y se distribuye en los bosques de las regiones costeras; las plantas han mostrado potencial para la producción de biodiesel, y la proteína cruda puede utilizarse para alimentación animal. Sin embargo, sus variedades actuales tienen bajo rendimiento y variabilidad en la producción, por estar en periodo de domesticación. El conocimiento de los granos de polen es fundamental para el estudio de la biología reproductiva de Jatropha y mejoramiento genético para generar nuevos híbridos y mejorar el rendimiento de frutos y semillas. Este estudio compara la morfología del polen de cuatro especies de Jatropha, que incluyen dos variedades de $J$. curcas, (una tóxica de India y una no tóxica de México) y dos variedades silvestres de $J$. cinerea (Sinaloa y Baja California Sur), por último, se obtuvo polen de $J$. platyphylla (Sinaloa) y J. vernicosa (Baja California Sur) silvestres para caracterizarlos palinológicamente. Para describir el tamaño y la forma de los granos de polen, se utilizó un microscopio electrónico de barrido. Los granos de polen tienen forma esferoidal. El diámetro de las variedades de $J$. curcas tóxica y no tóxica, y $J$. platyphylla fueron $58 \pm 2.3,54 \pm 1.7$, y $51 \pm 2.4$ micras, respectivamente; el número de clavas fue de $84 \pm 10,108 \pm 15$ y 180 \pm 15.5 , respectivamente. Los granos de polen de $J$. cinerea (Sinaloa) tienen un diámetro de $50 \pm 1.7$ micras y $220 \pm 14$ clavas por zona; J. cinerea (Baja California Sur) tiene un diámetro de $45 \pm 1.9$ micras y $195 \pm 14.7$ clavas. Los granos de polen de $J$. vernicosa tienen un diámetro de $46 \pm 2.1$ micras y $231 \pm 25.6$ clavas. La ornamentación de la exina mostró clavas con cápita en forma de gema y pequeños báculos en el lumen para ambas $J$. curcas y en forma de clavum para $J$. cinerea, J. platyphylla y $J$. vernicosa y no presentan báculos en el lumen. Las variedades estudiadas tienen una endexina reticulada y ectexina intectada.

Palabras clave: Palinología, J. curcas (tóxica y no tóxica var.), J. cinerea, J. platyphylla, J. vernicosa, planta endémica.

\section{REFERENCES}

Achten, W. M., Nielsen, L. R., Aerts, R., Lengkeek, A. G., Kjær, E. D., Trabucco, A., Hansen, J. K., Maes, W. H., Graudal, L., Akinnifesi, F. K., \& Muys, B. (2010). Towards domestication of Jatropha curcas L. Biofuels, 1(1), 91-107. http://www.tandfonline.com/ doi/full/10.4155/bfs.09.4

Bahadur, B., Ramanujam, C. G. K., Murthy, G. V. S., Goverdhan, S., \& Kalpana, T. P. (2000). A comparative analysis of LM and SEM studies of Jatropha L. (Euphorbiaceae) pollen. Geophytology, 28(1-2), 67-75.

Bahadur, B., Murthy, G., \& Sujatha, M. (2013). Pollen of Jatropha L. Taxonomic and Phylogenetic Considerations. In B. Bahadur, M. Sujatha, \& N. Carels (Eds.), Jatropha, Challenges for a New Energy Crop: Volume 2: Genetic Improvement and Biotechnology (pp. 45-74). New York: Springer Science + Business Media.

Chang-wei, L., Kun, L., You, C., \& Yongyu, S. (2007). Floral display and breeding system of Jatropha curcas L. Forestry Studies China, 9(2), 114-119. doi: 10.1007/ s11632-007-0017-z

Dehgan, B. (1984). Phylogenetic Significance of Interspecific Hybridization in Jatropha (Euphorbiaceae). Systematic Botany, 9(4), 467-478. doi: 10.2307/2418796

Dehgan, B., \& Webster, G. (1979). Morphology and Infrageneric Relationships of the genus Jatropha (Euphorbiaceae). Los Angeles, CA. EUA: University California Press.

Erdtman, G. (1952). Pollen Morphology and Plant Taxonomy Angiosperms: An Introduction to Palynology. Stockholm, Sweden: Almquist \& Wiksell.

Escoto-González, L., Flores-Ceballos, R., \& MaytorenaGarcía, E. (2013). Análisis de Variables Críticas en la Cadena AgroIndustrial de Jatropha curcas. In G. Escoto, I. Contreras, \& M. Angulo-Escalante (Eds.), Cadena AgroIndustrial de Jatropha curcas: Paquetes tecnológicos para el Noroeste de México (pp. $267-$ 338). Saarbrücken, Alemania: Publicia.

Heller, J. (1996). Physic nut Jatropha curcas L. Promoting the conservation and use of underutilized and neglected crops. Institute of Plant Genetics and Crop Plant 
Research, Gatersleben/ International Plant Genetic Resources Institute, Rome.

Jongschaap, R. E. E., Corré, W. J., Bindraban, P. S., \& Brandenburg, W. A. (2007). Claims and facts on Jatropha curcas L. Global J. curcas evaluation, breeding and propagation programme (Report 158). Retrieve from http://library.wur.nl/way/bestanden/ clc/1858843.pdf

León de la Luz, J. L., Domínguez-Cadena, R., Domínguez-León, M., \& Coria-Benet, R. (2014). Flora Iconográfica de Baja California Sur 2. S.C. La Paz, B.C.S. México: Centro de Investigaciones Biológicas del Noroeste.

Makkar, H. P. S., Kumar, V., Oyeleye, O. O., Akinleye, A O., Angulo-Escalante, M. A., \& Becker, K. (2011). Jatropha platyphylla, a new non-toxic Jatropha species: physical properties and chemical constituents including toxic and antinutritional factors of seeds. Food Chemistry, 125(1), 63-71. http://dx.doi. org/10.1016/j.foodchem.2010.08.037

Mc Vaugh, R. (1945). The genus Jatropha in America: principal inter-generic groups. Bulletin of the Torrey Botanical Club, 7(3), 271-294. doi: 10.2307/2481288

Raju, A. J. S., \& Bahadur, B. (2013). Breeding system and pollination in Jatropha curcas L. In B. Bahadur, M. Sujatha, \& N. Carels (Eds.), Jatropha, Challenges for a New Energy Crop: Volume 2: Genetic Improvement and Biotechnology (pp. 423-444). New York: Springer Science + Business Media.

Rianti, P., Suryobroto, B., \& Atmowidi, T. (2010). Diversity and Effectiveness of Insect Pollinators of Jatropha curcas L. (Euphorbiaceae). HAYATI Journal of Biosciences, 17(1), 38-42. http://dx.doi.org/10.4308/ hjb.17.1.38

Sáenz-Laín, C. (2004). Glosario de términos palinológicos. Lazaroa, 25(1), 93-112. http://revistas.ucm.es/index. php/LAZA/article/view/LAZA0404110093A/9088
Saenz de Rivas, C. (1976). Sobre la Nomenclatura Palinológica: La Esporodermis. Anales Instituto Botánico Cavanilles, 33(1), 159-177. http://www.rjb.csic.es/ jardinbotanico/ficheros/documentos/pdf/anales/1976/ Anales_33(1)_159_177.pdf

Salinas, N., Armijos, V., Jiménez, P., \& Proaño, K. (2011). Caracterización y estudio de la diversidad genética del Piñón (Jatropha curcas) mediante el uso de marcadores moleculares. Ciencia, 4(1), 31-40.

Sosa-Segura, M., Oomah, B., Drover, J., Heredia, J., Osuna-Enciso, T., Valdez-Torres, J., Salazar-Villa, E., Soto-Landeros, F., \& Angulo-Escalante, M. (2014). Physical and Chemical Characterization of Three Non-Toxic Oilseeds from the Jatropha Genus. Journal of Food and Nutrition Research, 2(1), 56-61. doi: 10.12691/jfnr-2-1-10

Sujatha, M., Bahadur, B., \& Reddy, T. P. (2013). Interspecific Hybridization in the Genus Jatropha. In B. Bahadur, M. Sujatha, \& N. Carels (Eds.), Jatropha, Challenges for a New Energy Crop: Volume 2: Genetic Improvement and Biotechnology (pp. 423-444). New York: Springer Science + Business Media.

Sunil, N., Kuma, V., \& Varaprasad, K. S. (2013). Origin, Domestication, Distribution and Diversity of Jatropha curcas L. In B. Bahadur, M. Sujatha, \& N. Carels (Eds.), Jatropha, Challenges for a New Energy Crop: Volume 2: Genetic Improvement and Biotechnology (pp. 137-152). New York: Springer Science + Business Media.

Wang, X. R., \& Ding, G. J. (2012). Reproductive biology characteristic of Jatropha curcas (Euphorbiaceae). Revista de Biología Tropical, 60(4), 1525-1533. Retrieve from http://www.redalyc.org/articulo. oa? id $=44925088009$

Wilbur, R. L. (1954). A synopsis of Jatropha, subsections Eucurcas, with the description of two new species from Mexico. Journal Elisha Mitchell Scientific Society (70), 92-101. 